Article

\title{
Scenarios for Coal-Exit in Germany-A Model-Based Analysis and Implications in the European Context
}

\author{
Martin Kittel ${ }^{1,2, *} \mathbb{C}$, Leonard Goeke ${ }^{2}$, Claudia Kemfert ${ }^{1}$, Pao-Yu Oei ${ }^{2}{ }^{\mathbb{D}}$ and \\ Christian von Hirschhausen ${ }^{2}$ \\ 1 Department of Energy, Transportation, Environment, German Institute for Economic Research (DIW Berlin), \\ 10117 Berlin, Germany; ckemfert@diw.de \\ 2 Workgroup for Infrastructure Policy, TU Berlin, 10623 Berlin, Germany; lgo@wip.tu-berlin.de (L.G.); \\ pyo@wip.tu-berlin.de (P.-Y.O.); cvh@wip.tu-berlin.de (C.v.H.) \\ * Correspondence: mkittel@diw.de
}

Received: 6 February 2020; Accepted: 10 April 2020; Published: 20 April 2020

\begin{abstract}
The political discussion to reduce the carbon footprint of Germany's electricity sector, focusing on coal, is intensifying. In this paper, we develop scenarios for phasing out lignite and hard coal power plants in Germany prior to the end of their technical lifespan ("coal-exit"). Our analysis bases upon two coal-exit instruments, the retirement of coal generation capacities and the limiting of how much aged coal power plants with high carbon intensity can be used within a year. Results show that phasing out coal in Germany would have a considerable impact on Central European electricity markets, in terms of decarbonization efforts and electricity trade. An ambitious coal-exit could avert foreseeable shortcomings in Germany's climate performance in the short-run and release additional carbon savings, thus compensating for potential shortfalls in other energy-intensive sectors by 2030 . Limited emissions in the range of $27 \%$ would be shifted to neighboring countries. However, tremendous positive climate effects on European scale would result, because Germany's annual emission savings in 2030 would be substantial. Totaling 85 million tons of $\mathrm{CO}_{2}$, the overall net reduction is equivalent to $17.5 \%$ of total European emissions in 2030 without retirements of coal-firing power plants prior to the end of their technical lifespan.
\end{abstract}

Keywords: energy transition; Germany; energiewende; electricity modeling; coal phase-out; energy policy; climate policy

\section{Introduction}

\subsection{Motivation}

Germany has not been particularly stringent with respect to reducing greenhouse gas emissions in the 2010s. In fact, the initial goal of reducing greenhouse gas emissions by $40 \%$ by 2020 (basis: 1990) will be missed by a wide margin (7\%), neglecting possible short-term reductions as a consequence of the coronavirus pandemic in 2020. Thus, efforts must be strengthened if the goal to cut emission by $55 \%$ by 2030 is to be met [1]. Since the signing of the Paris Agreement, however, pressure by political actors, civil society and climate movements (e.g., Fridays for Future, Ende Gelände) has increased. As part of its transformation to a low-carbon energy system, generally called "energiewende", Germany is therefore evaluating options to reduce its $\mathrm{CO}_{2}$ emissions from the coal sector, by far its largest single emitter at about $250 \mathrm{Mt}$ (2017). Germany hereby follows other European countries that have already implemented policies to reduce their reliance on coal-fired electricity provision, or simply to define concrete timetables for phasing out coal ("coal-exit"), including Denmark, France, the Netherlands, and the UK. 
Coal, formerly the backbone of Germany's economy since the second world war [2,3] is risking to become the Achilles heel of its energy transition in the 21st century. Within this context also the public perception of coal is undergoing a shift [4]. Rinscheid and Wüstenhagen find that a majority of citizens would support a relatively rapid phase-out by 2025 [5]. In addition, coal regions are putting pressure on the government asking for financial support to ease the upcoming transition and related employment effects [6]. The resulting "Commission on Growth, Structural Change and Employment" —often also referred to as "coal commission" - recommended a coal phase-out by 2035-2038 [7]. Appendix A provides further details on the German coal commission. This phase-out schedule will be implemented within a coal phase-out law in late summer 2020. This outcome was celebrated by some as a unique settlement between all involved actors and criticized heavily by others stressing that an earlier phase-out by 2030 is required to meet Germany's climate targets [8,9].

The German electricity system is strongly interconnected with the rest of the European system. The planned coal phase-out, in addition to the closure of the remaining nuclear power plants (another 9.5 GW to be shut down by 2022), will therefore have strong effects on its neighboring countries, both with respect to resource adequacy and also overall $\mathrm{CO}_{2}$ emissions. Germany is a large net exporter of electricity (around 50 TWh in 2017, i.e., about $10 \%$ of its electricity generation) and a reduction in its surplus might create shortages in other countries. An increase of (fossil-fuel based) electricity production outside of Germany also might offset (parts of the) $\mathrm{CO}_{2}$ mitigation efforts within Germanybeing referred to as "waterbed effect". Recent research as well as the recommendations of the coal commission therefore emphasize that the reduction of $\mathrm{CO}_{2}$ emissions in Germany need to be taken out of the ETS-market to safeguard the overall climate objectives [10].

In this paper, we develop scenarios for phasing out lignite and hard coal power plants in Germany, then calculate the energy and climate effects on both the German and the European electricity systems, with respect to trade flows, electricity mix and $\mathrm{CO}_{2}$ emissions. We are particularly interested in long-term resource adequacy, i.e., the availability of sufficient generation capacity to meet demand, as well as the overall $\mathrm{CO}_{2}$ emissions of the electricity system. We use an established, large-scale model called dynELMOD (dynamic electricity model), a dynamic partial equilibrium model of the European electricity system until 2050 posed as a linear optimization problem [11]. The model decides on cost-optimal investment and dispatch for conventional and renewable power plants, storage systems, demand-side management and high-voltage transmission lines.

\subsection{Literature Review}

While it is widely recognized that compliance with climate targets requires a phase-out coal, the instruments to achieve this are subject to debate.

Heinrichs and Markewitz compare a German coal-phase out along a predetermined path with other options to mitigate emissions [12]. To this end they apply a model of the entire energy system, which optimizes investment decisions until 2050 under myopic foresight. The analysis is based on three scenarios: In a reference scenario all coal-fired power plants run until the end of their technical lifetime. In the second scenario, coal power plants with technical lifetimes exceeding 2040 are switched off in 2040. In a third scenario, the same reduction of emissions as in the phase-out scenario has to be achieved, but the model can endogenously decide on measures to do this. Overall, model results show that the considered phase-out pathways result in a substantial reduction of emissions. However, as a stand-alone policy measure, they are insufficient for complying with political targets of reducing emission by $55 \%$ until 2030 and by $80 \%$ until 2050 , compared to 1990 levels. This is mainly because reductions are limited to the power sector. Compared to the reference scenario, some sectors even show an increase in emissions. If the model is allowed to achieve the same amount of reduction freely, the estimated costs of avoiding emissions are $10 \%$ smaller, mainly because less efficient lignite plants are phased out preferably. Based on these model results, they conclude that an extension of the European emission trading scheme could achieve the cost-efficient solution identified in the third scenario. 
Not extending, but complementing the European trading scheme with national measures of carbon pricing to phase-out coal is something investigated by Wilson and Staffell [13]. They analyze the impact of Great Britain's carbon tax implemented as price floor complementary to the European trading scheme. They find the tax induced a rapid fuel switch from coal to gas that decrease overall emissions in Great Britain by $6 \%$. However, they stress results cannot simply be transferred to other countries. In Germany a rapid fuel switch seems possible and could achieve a similar reduction in carbon emissions, because there is a sufficient amount of underutilized gas power-plants. However, since the German electricity market is much more connected with neighboring countries, the risk of carbon leakage increases.

Osorio et al. have a closer look on the effect a national carbon price floor for Germany has on national and European emissions [14]. Their results highlight how much the interconnection of European electricity markets affects the national climate policy: Depending on the power markets developments and climate policies in other countries, the carbon price floor required for Germany to meet its 2030 climate target ranges from 33 to $57 € / \mathrm{tCO} 2$. The effect German reductions have on other European countries is again highly dependent on how the European emission trading scheme will develop. In the long run, German reductions could almost entirely be offset by additional emissions from other countries due to the increase in emission allowances. Such an effect could be avoided if Germany cancels emission certificates in addition to introducing a price floor.

\subsection{Research Question and Summary Findings}

This paper contributes to the literature on the low-carbon transformation by shedding light on the effects of phasing out coal in Germany, within the European context. Unlike existing research, it focuses on the power sector, where a coal phase-out has the greatest effect by far. This approach also allows for capturing the effects of a German coal phase-out on power generation in other European countries.

More specifically, our research question is two-fold. First, what are the effects of a coal phase-out in Germany in terms of generation patterns, installed capacity and future investments, and climate performance on i) the German and ii) the European electricity market? The effects, in turn, would need to be considered in the internal discussions of the phase-out in Germany, where the discussion is becoming tenser as pressure to achieve greenhouse gas emission reductions is increasing.

Therefore, the present paper identifies possible pathways for the lignite and hard coal phase-out in Germany within the context of the European electricity system. For each path, a model calculation of the European electricity system analyzes the effect on carbon emissions and describes the resulting mixture of generation technologies. Our findings show that a rapid coal phase-out in Germany leads to a significant modification of generation patterns and trade flows between Germany and its neighbors. The fears of a major transfer of coal emissions from Germany to other countries, however, can be mitigated: As the German coal mix is by far the most $\mathrm{CO}_{2}$-intensive one, overall European emissions are reduced significantly-by up to $85 \mathrm{Mt} \mathrm{CO}_{2}$ in 2030, amounting to $17.5 \%$ of total emissions in the reference scenario-in the case of a German coal phase-out, as compared to no coal phase-out policies. Interestingly, neither coal- nor nuclear-based electricity provision of the neighbors increases significantly: Poland, the second largest coal country, is using its capacities broadly, and only increases its generation using natural gas. Likewise, Germany's western neighbors do not increase their nuclear electricity generation as they are already running at full capacity. The model results emphasize that unilateral decisions by one country, e.g., the coal phase-out in Germany, need to be analyzed, prepared and executed with at least its neighbors, if not the entire European electricity system, in mind. Unilateral capacity and system adequacy planning, sometimes still stipulated by domestic stakeholders, does not make any sense in this context and the planning instrument of "national electricity balances" has been rightfully abandoned in Germany (and at the European level) in order to support an overall European low-carbon energy transformation.

The remainder of the paper is structured as follows: The next section describes the scenarios for different speeds of the coal phase-out in Germany, provides a brief description of the model, and the 
data used. Section 3 presents the results with respect to the electricity mix, trade flows, and emissions, both in Germany and in the larger European context. Section 4 discusses these results and places the potential German phase-out in the European context.

\section{Methodology: Scenario Development and Model Description}

\subsection{Scenarios for a German Coal Phase-Out}

The present study analyzes implications of a coal phase-out in Germany on the emissions of the electricity sector, electricity generation mixes and national electricity trade accounts in Germany and on European electricity markets. The analysis was based upon a reference scenario and four coal-exit pathways with shut downs of coal power plants before they reach their technical lifetime. The reference scenario REF represents a business-as-usual continuation of German energy and climate policy regulation dating to August 2018 and updates available power generation capacities in Germany. Previously transferred back-up capacities, such as the capacity reserve (in German: Sicherheitsbereitschaft) were considered. This reserve holds lignite power plants on stand-by and gradually increases to a total of $2.7 \mathrm{GW}$ as more power plants were transferred, beginning in 2016. After four years on stand-by, the power plants are decommissioned, such that the Sicherheitsbereitschaft is completely dispersed in 2023 [15]. Power plants are retired once they reach the end of their assumed technical lifetime [11]. Without any additional political interventions considered, this would yield a continuation of coal combustion beyond 2050. Retrofitting of power plants, one option to prolong their technical lifetime, is not permitted. Our reference assumption framework foresees the phase-out of lignite power plants by 2050, while hard coal power plants are shut down beyond 2050. The available exogenous European-wide carbon budget is aligned with a linear decarbonization pathway envisaged by the European Union mandating an overall reduction of $98 \%$ by 2050 [16]. Appendix B details additional scenario assumptions.

Besides the reference scenario (REF), we modeled four coal-exit pathways for Germany: First, one scenario using the capacities of the reference case with a limitation of the annual operation time of aged coal power plants (REF-flh). Second, one phase-out scenario closing down coal power plants additional to the reference scenario at a moderate rate (MODERATE). Third, one scenario using this moderate coal exit schedule in conjunction with the aforementioned full-load hour (flh) reduction of aged coal power plants remaining online (MODERATE-flh). Last, one scenario retiring coal power plants at a rapid rate (RAPID). Table 1 illustrates installed hard-coal and lignite generation capacities available within our scenarios over time. The capacities are derived from coal-exit schedules suggested by German policy-makers, in conjunction with emissions performance standards implemented in other countries that used to or still heavily rely on coal combustion. The MODERATE scenario was based on a coal-exit proposal from German coalition talks in November 2017, which was favored by the parties CDU/CSU and FDP. It foresees a reduction of coal-fired capacities of 5 GW by 2020, compared to the available power plant stack in 2017. The capacity continuously decreases until 2030, representing a reduction of $70 \%$ of the available generation capacity in the reference scenario in 2020. Lignite capacities are initially reduced, then completely removed from operation by 2030. In the same year, the phase-out of hard coal power plants begins and is completed in 2040. Capacities of intermediate time steps were linearly interpolated and adjusted to fit the actual available power plant stack. Additionally, the RAPID exit constitutes a more stringent coal phase-out pathway: By 2020, the available coal generation capacity in 2017 is reduced by 9 GW. By 2030, 18 GW are retired compared to the base case. In terms of total available coal capacity, this scenario approximates the coal commission's recommendation [7].

We investigated two different coal-exit policy instruments: First, a mandated retirement of coal-fired power plants in the order of the aforementioned capacity reductions. This 'command and control' approach is a common sectoral regulation, with the allocation directly determined by the government [17]. Second, limiting the annual operating time of coal power plants that are than 20 years online (by 2020). This is a soft phase-out policy measure and is held to be efficient in reducing emissions, 
while, at the same time, barely affecting the number of employees in the affected power plants [18,19]. Keeping coal power plants connected to the grid and limiting their operational hours to those with low renewable intake (and consequently higher wholesale prices) secures grid stability while still enabling profitability. The examined configuration restricts the annual operating time of coal-fired power plants more than 20 years old to maximum of 4000 full load hours per year [20]. In other words, a power plant of this age can generate on average at a load factor of $50 \%$. This is similar to other implementations of emissions performance standards in the UK, Canada, and select US states [21]. Another reason to limit full load hours could be the implementation of the newest European environmental directive on the best available techniques for large combustion plants (European Union's Industrial Emissions Directive). This directive takes effect in 2021 and includes stricter regulations on nitrogen oxide, sulphur dioxide, and mercury emissions that are not met by most older coal fired plants in Germany [22]. The full load hour (flh) reduction is applied to the base case (REF-flh) and the moderate pathway (MODERATE-flh).

Table 1. Hard coal and lignite capacities in the reference scenario REF and the investigated coal phase-out pathways with or without full load hour restrictions. Note that the scenarios REF and REF-flh, as well as the MODERATE and MODERATE-flh are based upon the same assumptions on available hard-coal and lignite capacities, respectively (own calculations).

\begin{tabular}{cccccccccc}
\hline Scenario & Technology & $\mathbf{2 0 1 5}$ & $\mathbf{2 0 2 0}$ & $\mathbf{2 0 2 5}$ & $\mathbf{2 0 3 0}$ & $\mathbf{2 0 3 5}$ & $\mathbf{2 0 4 0}$ & $\mathbf{2 0 4 5}$ & $\mathbf{2 0 5 0}$ \\
\hline REF (flh) & Hard coal & 24.7 & 19.1 & 19.1 & 16.5 & 9.9 & 7.3 & 7.2 & 7.0 \\
& Lignite & 21.0 & 18.2 & 17.6 & 10.2 & 9.3 & 9.0 & 5.6 & 0 \\
MODERATE (flh) & Hard coal & 24.7 & 19.1 & 19.0 & 12.9 & 6.8 & 0 & 0 & 0 \\
& Lignite & 21.0 & 13.2 & 3.6 & 0 & 0 & 0 & 0 & 0 \\
\multirow{2}{*}{ RAPID } & Coal & 24.7 & 19.1 & 14.8 & 8.6 & 3.1 & 0 & 0 & 0 \\
& Lignite & 21.0 & 9.2 & 3.6 & 0 & 0 & 0 & 0 & 0 \\
\hline
\end{tabular}

Germany is not the only country pondering a coal phase-out within Europe. Table 2 shows assumed exogenous coal-exit pathways based upon the extensive database of the Europe Beyond Coal initiative [23]. The implemented pathways are, wherever possible, aligned with concrete shut-down dates of coal power plants announced by the respective governments or linearly interpolated and adjusted to the capacity of available power plants. To fit the underlying model structure used in this study, the exit dates were approximated to five-year increments. Furthermore, a moratorium on capacity additions was imposed for countries that had announced a coal-exit. Note that, these coal-exit schedules date to August 2018. Meanwhile, until the date of publication, there have been rapid changes of coal-exit policies in some countries: The United Kingdom (UK) aims at completely phasing-out coal by 2025, Austria (AT) by 2020 and Denmark (DK) by 2030. This yield a slight overestimation of available coal capacities in Europe by our analysis.

Table 2. Assumed coal-exit dates for European countries (own calculations based on [23]).

\begin{tabular}{cccccccccccc}
\hline Country & AT & BE & DK & FI & FR & IE & IT & NL & PT & SE & UK \\
\hline Phase-out year & 2030 & 2020 & 2035 & 2030 & 2025 & 2030 & 2030 & 2030 & 2035 & 2025 & 2030 \\
\hline
\end{tabular}

\subsection{Model Description}

We used the dynamic partial equilibrium model dynELMOD (dynamic electricity model) [11]. The model represents the European electricity system and was posed as a linear optimization problem. The model determined the European mix of generation technologies and flexibility options consisting of power plants using conventional and renewable energy sources, storage systems and demand-side management facilities and their deployment. dynELMOD also output the expansion of interconnection points for cross-border trade of electricity.

It based its decision on current data for the European power plant portfolio and uses the existing electricity grid as a starting point. Additional inputs included forecasts on European electricity 
consumption, the costs and properties of the technologies under consideration, the historic, hourly time series of electricity demand and feed-in of renewable energy from the base year, 2013. To deal with the computational burden, these time series were reduced in a three-step procedure. First, starting with the 7th hour, every 49 th hour of the year was selected. Consequently, a new time-series of 179 representative periods was obtained. Next, the resulting time series were smoothed using a moving average. Lastly, the reduced time-series was scaled to retain key properties of the original time-series like minimum and maximum value or full load hours. A detailed description of the procedure could be found in Gerbaulet and Lorenz in [11].

Using these reduced time-series, the model minimized the total system costs of providing electricity by 2050 in five-year steps across 33 European countries divided into five synchronous grid zones (see Figure 1). Afterwards results could be validated by running separate dispatch computations with the full time-series for single years.

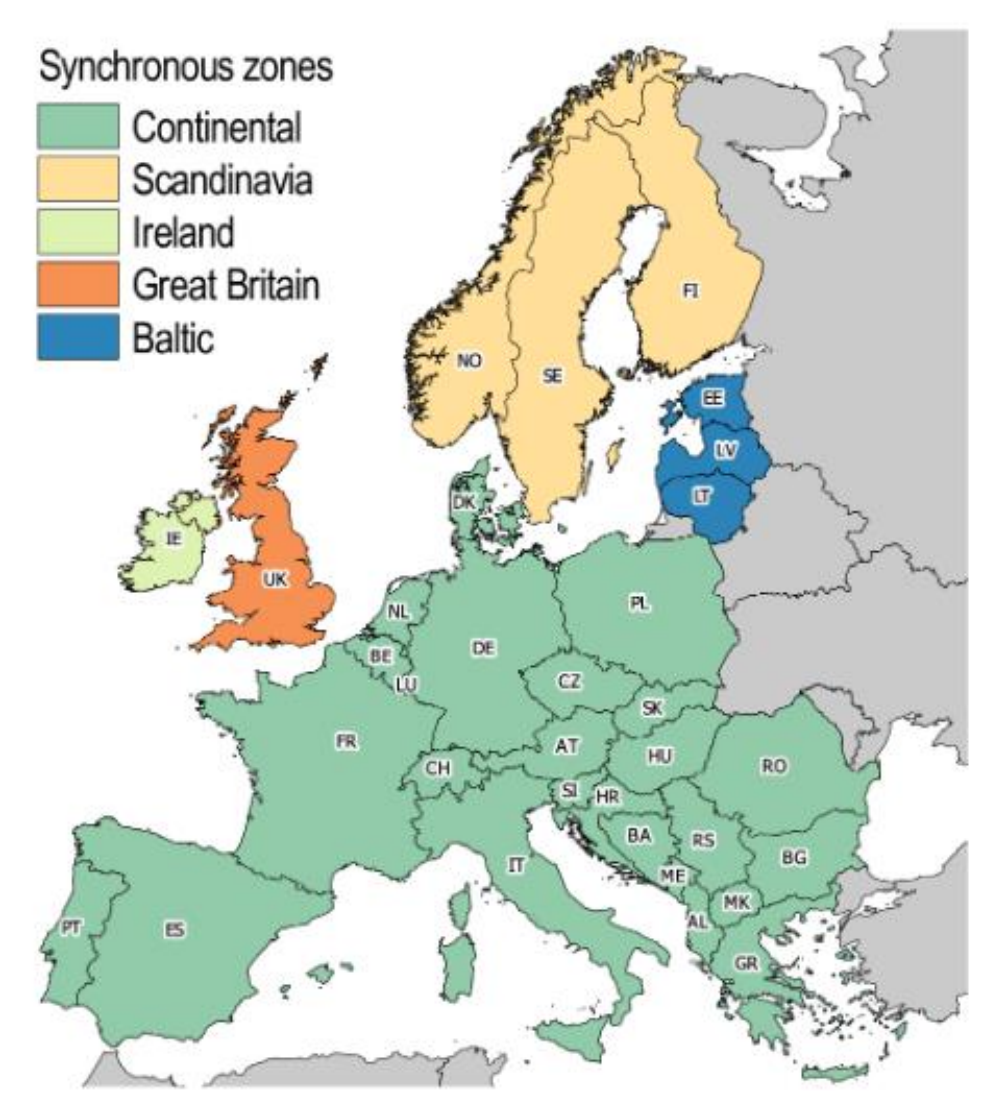

Figure 1. Dynamic electricity model (dynELMOD) geographical coverage (Gerbaulet and Lorenz, 2017).

The key condition of the model is an extensive decarbonization of the European electricity supply by 2050. In the model emissions can either be restricted by a yearly budget or a direct carbon price. In case of a yearly budget, emissions can freely be distributed across all countries considered. As a result, the shadow price on the carbon constraints can be interpreted as external carbon price required to achieve the set emission budget under the assumption of complete markets. In this way, emission-driven changes in utilization of thermal plants, like a fuel switch from coal to gas, are internalized via the emission constraint as well. In the calculations presented in this paper, a European emission limit for the power sector of $965.3 \mathrm{MtCO}_{2}$ equivalents in 2020 linearly decreasing to only $19 \mathrm{Mt} \mathrm{CO}_{2}$ equivalents in 2050 was used. Therefore, no direct carbon price was assumed, in order to not penalize emissions twice at the same time. All countries were equally subject to the same emission constraints and investment decisions were optimized based on these global conditions. Apart from binding coal (and nuclear) phase-out plants, national goals of energy policy were not considered. 


\section{Impacts of a Mandated German Coal Phase-Out on German and European Level}

In this section, we presented and analyzed implications of a coal-exit on German and European electricity generation, trade accounts and its contribution to greenhouse gas emission reduction.

\subsection{Generation, Trade and Emissions in Germany}

In the 2010s, a significant part of Germany's domestically generated electricity was exported. The net export surplus amounted to 53.7 TWh in 2016 [24]. Model results show that closing coal power plants ahead of their technical lifetime was likely to consolidate the German trade balance, as illustrated in Figure 2. In 2020 (Figure 2a), gross generation in Germany totals 669 TWh without additional energy policies, with 95 TWh net exports. When limiting the annual operating time of older coal power plants (REF-flh), total generation from coal power plants decreased by some $100 \mathrm{TWh}$, which was equally shared between hard coal and lignite power plants. This was partially offset by a higher gas output and strongly diminished net exports. The retirement of lignite-fired power plants in the MODERATE and RAPID exit scenario yielded a reduction of lignite generation of 35 and $65 \mathrm{TWh}$, respectively. This translated into a slight increase in gas generation and a significant decrease of net exports to neighboring countries at just below the same amount. When limiting the annual operational time of aged coal power plants, a fuel switch from coal to gas occurred. This is feasible, since, in the base case (REF), low-cost coal-based electricity pushed more cost-intensive gas power pants out of market. This result is in line with previous research [13]. For instance, in the MODERATE-flh scenario, lignite and hard coal generation lowered by 67 and 56 TWh, respectively, which was partially compensated by a higher output of otherwise idle gas-fired generation capacities in the order of $25 \mathrm{TWh}$. Similar fuel switches were observable in other coal-reliant countries, such as the United Kingdom [13]. Additionally, German electricity trade account consolidates as exports diminished by almost $100 \mathrm{TWh}$. The proportion of variable renewable electricity generation from wind and photovoltaics in Germany will increase, as assumed across all scenarios. Note that, due to our slight overestimation of available coal capacities in $\mathrm{AT}$, DK and the UK, gas generation and net exports in Germany might increase slightly, yet not to a significant extent.

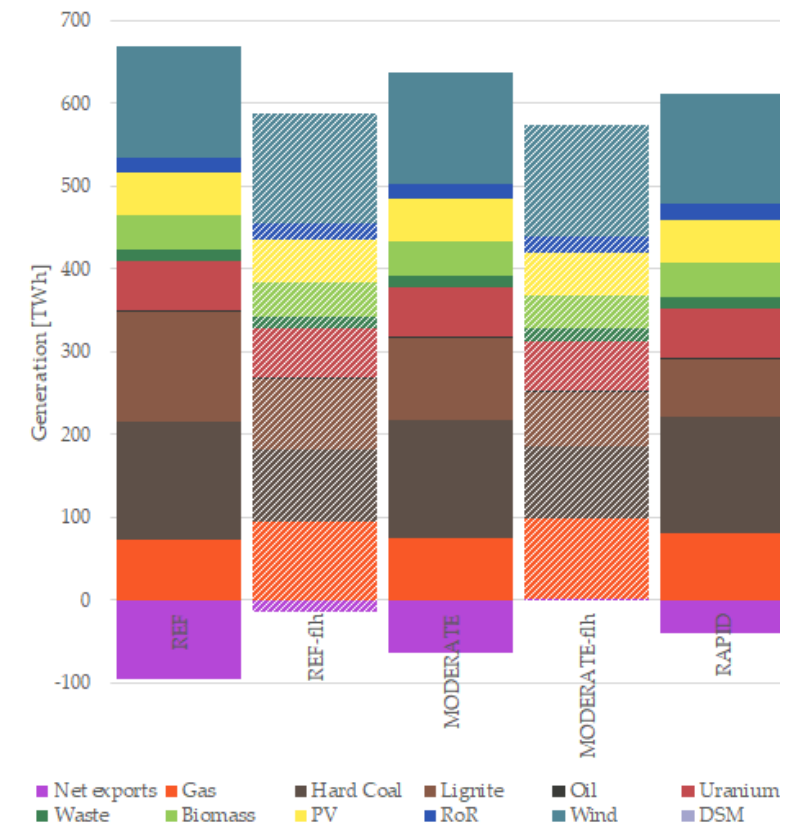

(a)

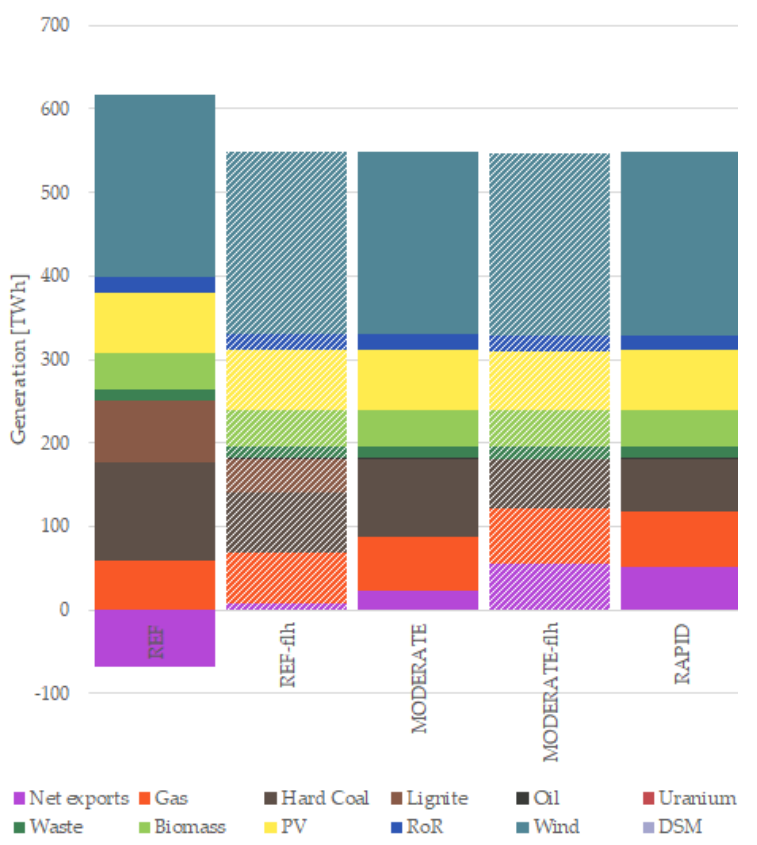

(b)

Figure 2. Electricity generation and trade in Germany in 2020 (a) and 2030 (b). Net imports are denoted positively, net exports negatively (own illustration). 
Due to the age-based culling of plants, the complete phase-out of nuclear power, and the switching off of coal-fired power plants in accordance with the phase-out paths, output from conventional generation will continue to decline in Germany in 2030 (Figure 2b). While under the base case assumptions Germany remains a net exporter of electricity, in all other investigated coal-exit pathways, Germany becomes a net importer of electricity. The more ambitious the coal-exit, the greater Germany's net imports, totaling a maximum of $55 \mathrm{TWh}$. This equals the amount of net exports in 2016. Apart from the REF-flh scenario, all lignite power plants were assumed to be retired by 2030 . Besides triggering higher net imports, gas and hard coal partially replace the eliminated lignite generation. The more stringent the coal-exit, the less generation from hard coal. Besides these impacts on conventional technologies, a coal-exit also facilitated the expansion of renewable energy sources: In any of the investigated coal-exit scenarios generation from wind increases by $2.5 \mathrm{TWh}$, such that the proportion of variable renewable electricity generation from wind and photovoltaics in Germany would increase by 2030. Intriguingly, this proportion was equally distributed across all coal-exit scenarios. However, net imports rose with the ambition level of the German coal-exit, which is further discussed in the next chapter. Although differing significantly in 2020, results of the scenarios MODERATE-flh and RAPID exit aligned closely in 2030. While in the former the reduction in generation from hard coal power plants was $4.5 \mathrm{TWh}$ higher than in the latter, the increase of imports was stronger by $4.1 \mathrm{TWh}$ (changes were compared to the base case, respectively). This finding revealed that, in terms of reduction of coal generation, the limitation of the annual operation time in conjunction with the retirement of coal power plants was more effective than the mere command and control approach, although this difference was almost fully compensated by higher imports.

Figure 3 illustrates the capacity expansion pathways for Germany under the RAPID scenario (due to our slight overestimation of available coal capacities in AT, DK and the UK the expansion of renewable energy sources might increase slightly, yet not to a significant extent). Despite the retirement of coal capacity, model results show no capacity additions in 2020. Considering the consolidating effect on the German electricity trade account, this finding suggests that there were structural overcapacities in the German electricity sector. In the short-run, these would be reduced by a German coal-exit.

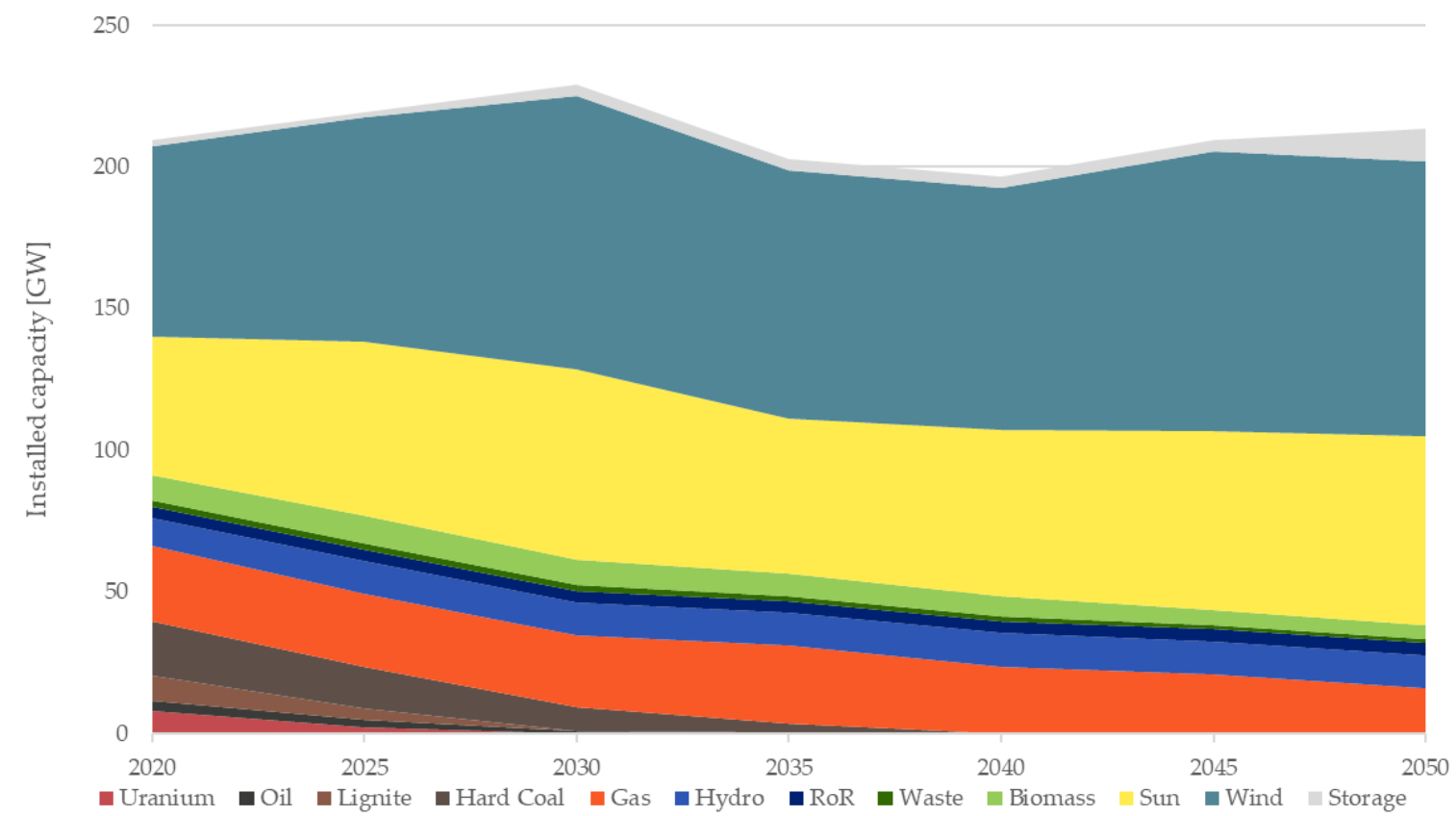

Figure 3. Installed capacity pathways for the RAPID exit over the model horizon (own calculations).

In contrast, retiring coal capacities before they reach the end of their technical lifetime would affect the cost-efficient mix of generation technologies in 2030. Instead of continued coal-based electricity, 
the energy system will expand toward renewable energy sources. Wind capacities are expanded by additional $2.5 \mathrm{GW}$ in 2030 in all coal-exit scenarios, while, compared to today's available power plants stack, none of the coal-exit pathways foresaw an expansion of thermal power plants. Consequently, the ratio of variable renewable capacity to dispatchable conventional capacity increased. This incentivizes the cost-optimal potential of load management. Except from the REF-flh scenario, the value of flexibility in the electricity system to accommodate renewable energy rose, resulting in an expansion of facilities that provided demand-side flexibility (demand-side management) by around $2 \mathrm{GW}$.

The model results show that a German coal-exit was an appropriate measure to decrease greenhouse gases emitted by the German electricity sector (with biomass being perceived as carbon-neutral). However, Figure 4 illustrates that not all investigated phase-out pathways were effective at meeting Germany's climate obligations (note that due to our slight overestimation of available coal capacities in AT, DK and the UK the usage of gas-fired power plants in Germany might increase slightly, thus also emissions, yet not to a significant extent). In fact, the sectoral 2020 target could only be achieved in the MODERATE-flh scenario. In this case, a surpass of the carbon savings target in the electricity sector, at just below $4 \mathrm{MtCO}_{2}$ equivalents, would be realized and could compensate for conceivable shortfalls in other energy-intensive sectors, such as transport. The mere command and control approach, or the reduction of full load hours only, will not suffice in the short-run; even though reducing full load hours appears to be more efficient in terms of emission reductions. While there are substantial emission reductions in either case, both the MODERATE and RAPID exit cases would miss the 2020 mark by $30 \%$ and $16 \%$, respectively. Emission reductions in the REF-flh lag only $7.5 \%$. behind. This finding shows that, in the short run, aged coal-fired power plants are one major driver of German greenhouse gas emissions and that limiting their operations is an efficient means to achieve carbon savings.

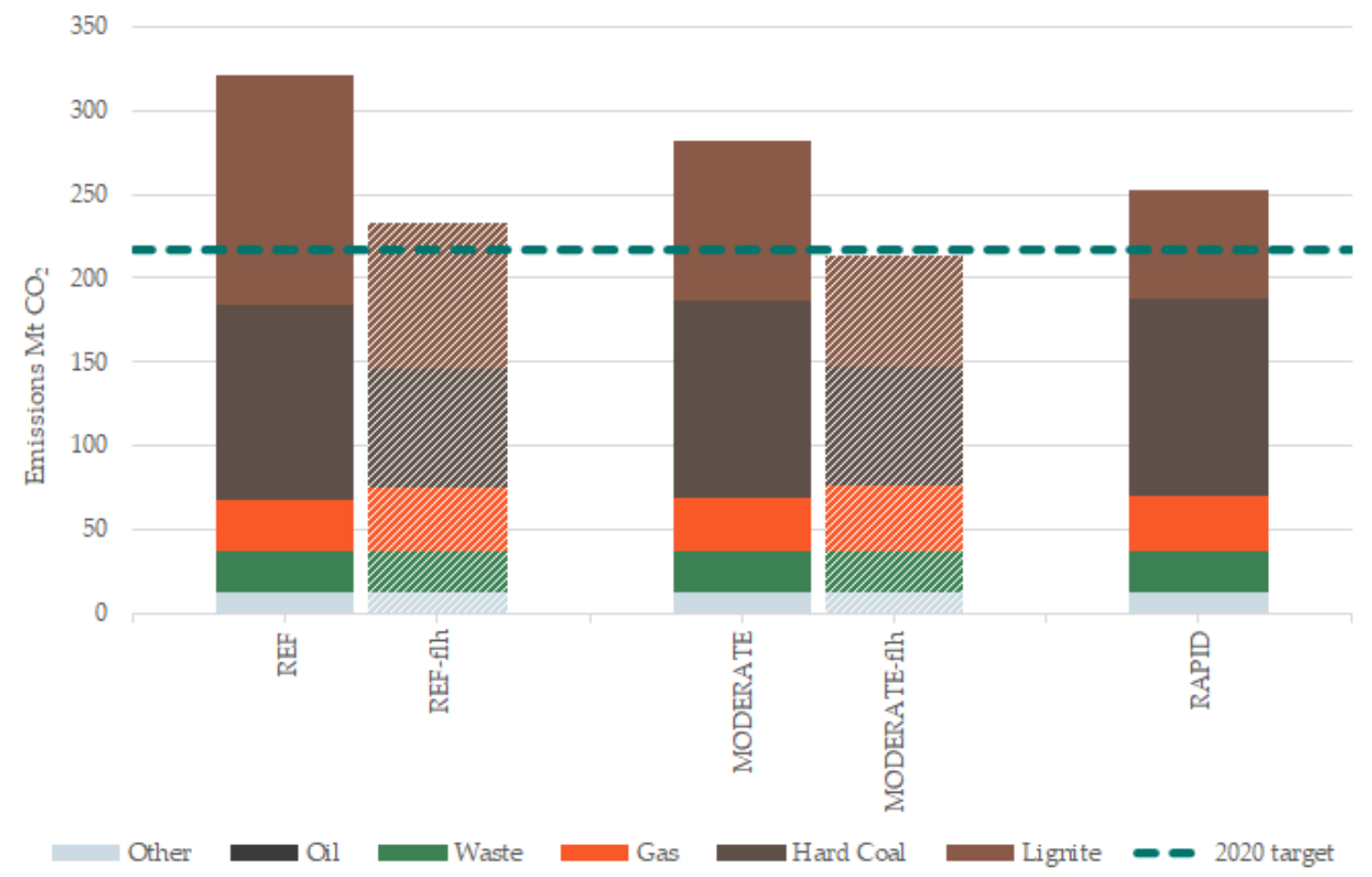

Figure 4. Emissions of the German electricity sector in 2020 (own calculations).

In the beginning of the middle of March 2020, societal and economic restrictions were imposed by the German government to limit the spread of the corona virus COVID-19. Economic sectors suffering from these restrictions are numerous: exhibitions, hotel industry, retail sector, manufacturing industries and airlines, just to name a few. Consequently, the economic activity in Germany partially came to a halt, significantly reducing electricity demand from affected sectors, thus also electricity provision from fossil fuels. Foreseeable short-terms effects in terms of Germany's climate performance amount to 
additional carbon savings of $5 \mathrm{MtCO}_{2}$ equivalents for the period between mid of March to mid of April 2020 [25]. Long-term effects are highly uncertain as they strongly hinge upon the time it takes until the coronavirus is under control, such that the restrictions can be eased and a resumption of economic activity becomes possible. Additionally, it remains uncertain whether there will be a persistent level shift of electricity demand due to economic effects, or whether it will rise up to pre-COVID-19 levels, or perhaps even beyond due to economic catch-up effects. Initial projections of potential additional carbon savings range from 15 to $35 \mathrm{MtCO}_{2}$ equivalents in 2020 (note that the figures for carbon savings due to the economic effects of COVID-19 are not a result of our model-based analysis, but are estimates detailed in [25]).

Based on the German climate action plan, the admissible sectoral emission budget for 2030 totals 141 $\mathrm{Mt} \mathrm{CO}_{2}$ equivalents; in Figure 5, the dashed line marks this. Difficulties arising in the decarbonization of other carbon- and energy-intensive sectors could yield tremendous reduction deficits in the German emission account. For example, current forecasts predict a short fall of $40-50 \mathrm{Mt}$ of $\mathrm{CO}_{2}$ equivalents by 2030 in the transport sector [26]. For the sake of illustration of sector target flexibility, Figure 5 displays conditions surrounding an $80 \%$ emission reduction in the electricity generation, with the admissible budget totaling $72 \mathrm{Mt} \mathrm{CO}_{2}$ equivalents. The resulting "flexibility corridor" represents emission reductions between $61 \%$ and $80 \%$ in the electricity sector. Similar to 2020, Germany's 2030 target can only be reached by intensifying the coal phase-out. Without any additional energy and environmental or climate policies, it will be missed by about $80 \mathrm{Mt} \mathrm{CO}_{2}$ equivalents, which is more than half of the available carbon budget. An ambitious energy policy could realize extensive emission reductions and put Germany on track to achieving its climate targets. Although there would be a slight increase in emissions from gas- and waste-fueled generation in the order of in the order of in total $4.6 \mathrm{Mt}$ $\mathrm{CO}_{2}$ equivalents, the overall net reduction effect is positive: carbon savings could surpass the 2030 target by approximately $25 \%$ or $35 \mathrm{Mt} \mathrm{CO}_{2}$ equivalents in the most stringent coal-exit scenarios. Notably, this holds true for both the moderate exit under full load hour restriction (MODERATE-flh) and the mere retirements in the RAPID exit. If lignite power plants were completely phased out, along with some hard coal plants retired (MODERATE), the objective will be exceeded by $10 \mathrm{Mt} \mathrm{CO}_{2}$ equivalents. The German climate targets, however, will have to be adjusted due to the planned increase of the European climate target of $-40 \%$ to $-50 \%-55 \%$ by 2030 (compared to 1990 ) [27,28]. It is to be expected that the moderate exit (MODERATE) would in that case not meet these more stringent targets. The limitation of the operational full load hours only is not even sufficient for meeting Germany's current 2030 climate targets. Note that, due to our slight underestimation of available coal-based generation capacities in AT, DK and the UK, the usage of gas-fired power plants in Germany might increase slightly, thus also emissions, yet not to a significant extent.

The greenhouse gas effect is a stock-flow problem, requiring a budgetary approach. That is, the total stock of greenhouse gases in the atmosphere is driving the effect, not the annual flow into the atmosphere. Potential carbon savings beyond the sector's target could offset excess emissions from earlier years 2010-2020. If, contrary to expectations, Germany's electricity sector also manages to comply with its climate targets in the short-run, a more stringent coal-exit coal could compensate for a lack of emission reductions in other sectors, providing flexibility for Germany's overall decarbonization at high cost efficiency. This implies that, in the medium-run, phasing out carbon-intensive lignite power plants could pave the way for compliance with Germany's climate policy targets.

Over the entire modeling horizon (2020-2050), the overall German emission reduction was tremendous, compared to total emissions in the baseline (REF). It ranged from $330 \mathrm{Mt} \mathrm{CO}_{2}$ equivalents, or $29 \%$, in the case of the REF-flh scenario, to more than $460 \mathrm{Mt} \mathrm{CO}_{2}$ equivalents in both the MODERATE-flh and the RAPID scenario, equivalent to over $40 \%$ of total emissions in Germany during the period 2020-2050. 


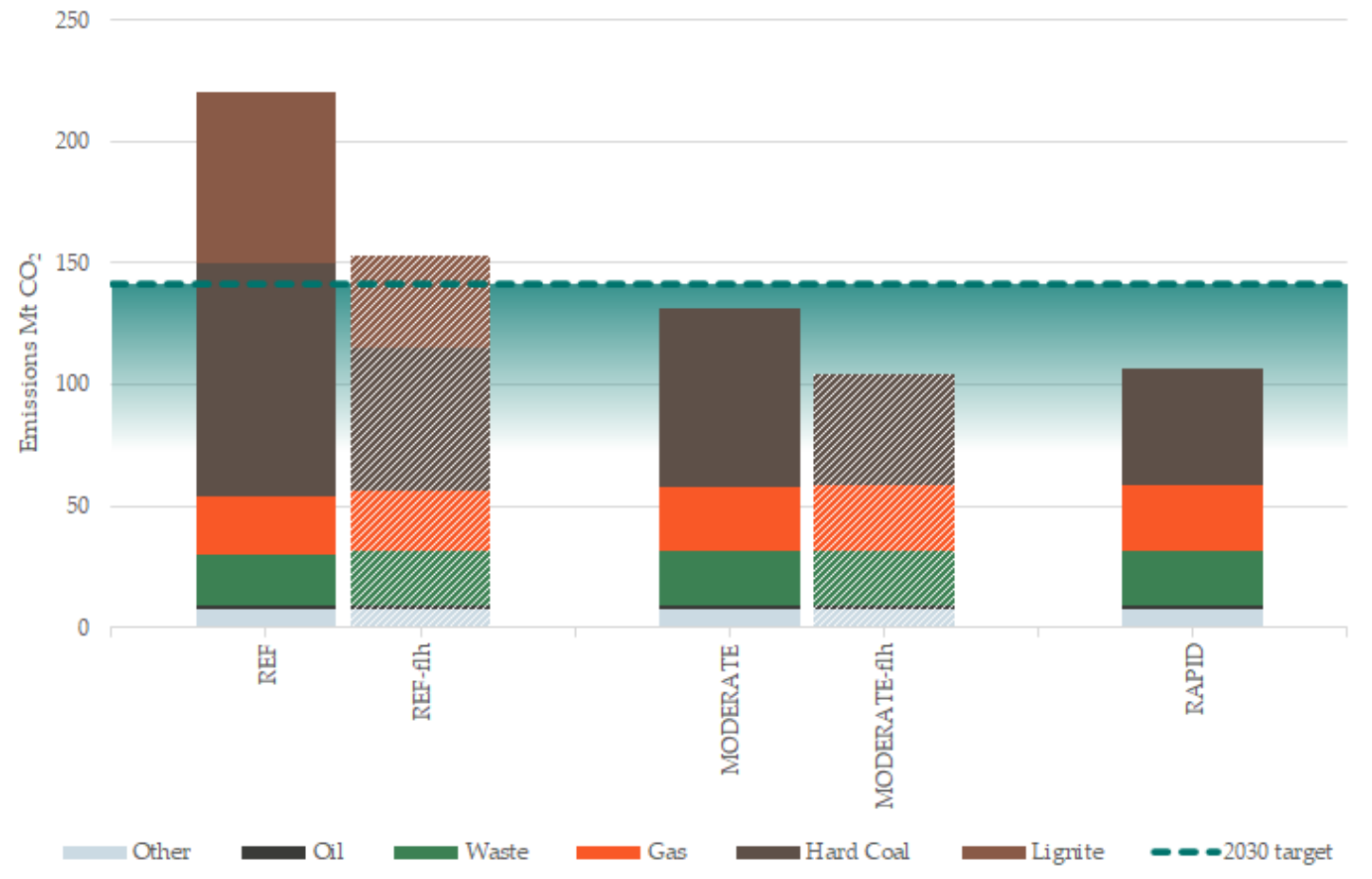

Figure 5. Emissions of the German electricity sector in 2030 (own calculations).

\subsection{Generation, Trade and Emissions in Europe}

As previously mentioned, a substantial part of Germany's electricity is exported. Domestic power plants in purchasing countries, generating at higher variable cost than the price of the imported electricity, are pushed out of market by Germany's excess generation according to the merit-order principle and remain idle. However, such imports are only economically viable if the imported electricity cannot be generated domestically at a lower cost. This is why German exports do not compete with domestic nuclear or lignite power plants located in importing countries, which are very likely to have lower variable cost than price of the imported electricity from Germany, thus being cost-competitive relative to German coal-fired power plants. Instead, German exports primarily displace lower-emission power plants (both domestically and abroad), such as gas [29]. Figure 6 illustrates the shift in generation within and outside Germany that would follow a decline in German coal-fired generation in 2020 (Figure 6a) and 2030 (Figure 6b). Figure 7 shows the corresponding shift in trade patterns of Germany and its neighbors, likewise in comparison to the base case (REF) in 2020 (Figure 7a) and 2030 (Figure 7b). Three effects become apparent: First, across all coal-exit scenarios there is a fuel switch from high-emission coal generation to technologies incurring lower or zero emissions (see Figure 6). Idle (and new) capacities entering the market are mainly gas power plants that otherwise would have remained pushed out of market both within and outside Germany, enabling higher net imports in Germany. Note that we conservatively accounted for direct emissions from the provision of electricity, that is, emissions from the combustion of conventional natural gas. Due to our slight overestimation of available coal capacities in $\mathrm{AT}$, DK and the UK, the decrease of coal-based generation would decrease slightly, while gas generation would increase to a similar extent. The overall dynamics illustrated here, however, remain the same.

Second, reduced German coal generation lowers German exports significantly in both 2020 and 2030 (see Figure 7a,b), as discussed in Section 3.1. This allows for increased electricity generation of otherwise idle and new capacities outside and within Germany generating at higher marginal cost as well as exports of neighboring countries. The amplitude of this effect is strongly correlated with the extent of the reduction of generation of coal power plants in Germany. In 2020, the effect primarily occurred under full load restriction of aged German coal power plants. This is plausible, as in the command and control approach, power plants with a capacity of only 5 (MODERATE) or 9 (RAPID) 
GW were assumed to leave the market. All remaining power plants could be operated consistently at an unchanged high capacity factor throughout the year. However, in 2030 the command and control approach appeared to be more effective in consolidating Germany's trade account than the limitation of the annual operational time of aged power plants alone. Many of the restricted aged power plants dispatching in 2020 would have reached the end of their technical lifetime by 2030. Thus, retiring the latest coal power plants vintage would exert a stronger influence on Germany's, as well as its neighbor's, generation and net exports. Due to our slight overestimation of available coal capacities in AT, DK and the UK, the export capacities of these countries might slightly decrease, such that their trade accounts would decrease to a similar extent. The overall dynamics illustrated here, however, remain the same.

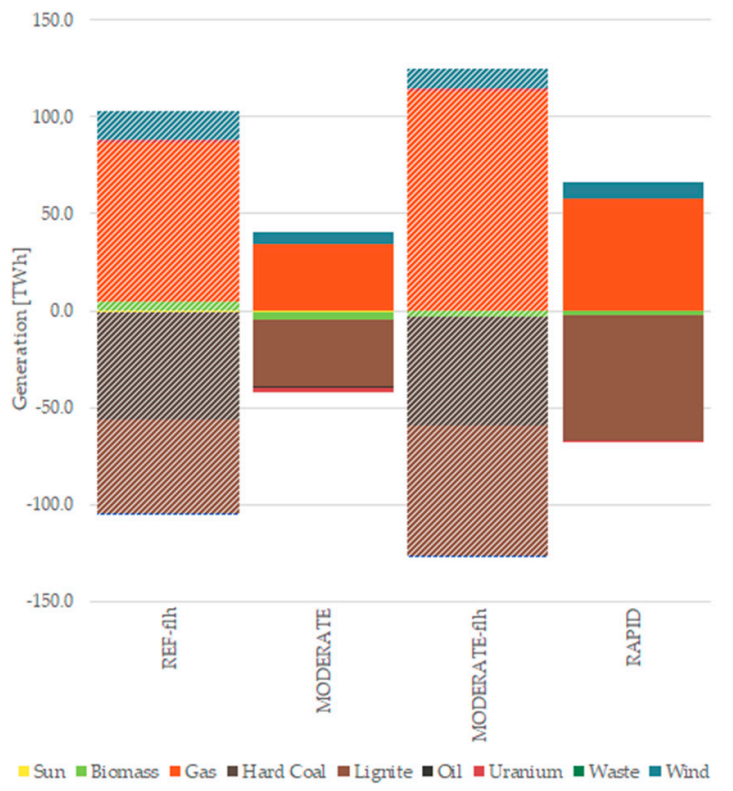

(a)

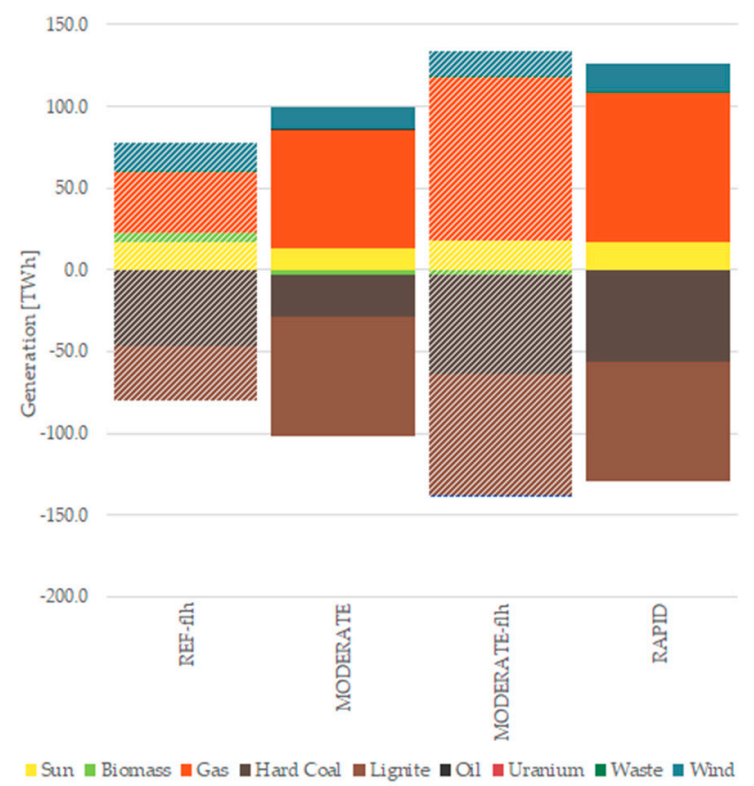

(b)

Figure 6. Shift in electricity generation across Europe in 2020 (a) and 2030 (b) as a result of a German coal-exit relative to the base case (own calculations).

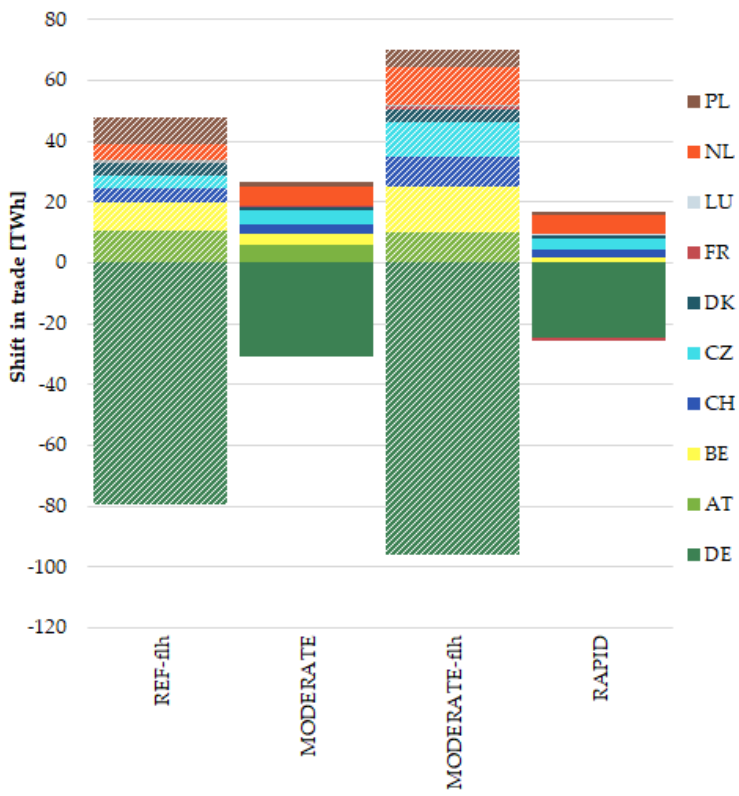

(a)

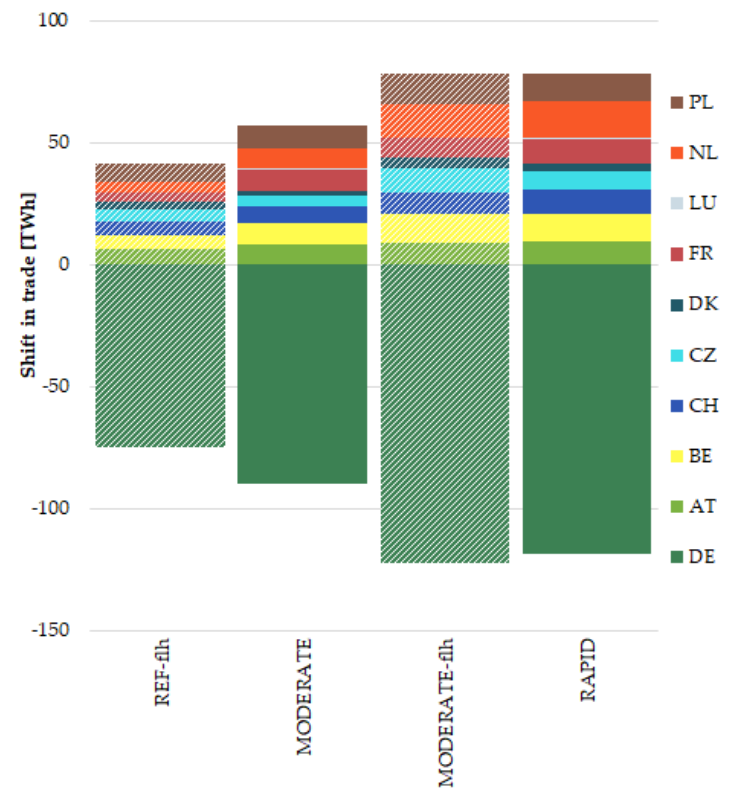

(b)

Figure 7. Shift in of the trade accounts of central European countries in 2020 (a) and 2030 (b) relative to base case (own depiction). 
Third, there is an extra incentive for expanding renewable energy because the option of cheap imported German coal-fired electricity would no longer be available, thus a German coal-exit enhances European decarbonization by advancing renewable energy sources. In 2020, this is primarily onshore wind in Denmark and Norway, which due to underlying spatially differentiated feed-in characteristics have a comparative cost advantage over Germany. In 2030 this is both solar PV primarily in Italy and wind primarily in the Nordic countries, which, again benefit from beneficial feed-in characteristics compared to Germany (see Figure 6b). Gerbaulet and Lorenz in [11] elaborate on this effect. Concerns regarding a German coal phase-out shifting electricity generation to other controversial technologies in neighboring countries—such as French nuclear power or Polish lignite-are unfounded. In fact, nuclear power plants in France already run at full capacity. Our model results show that, in the short-run, there was hardly any change in the French energy mix, with minor gas capacity additions of about $500 \mathrm{MW}$. In 2030, the expansion of wind power on the order of four to five GW was incentivized. Concomitant, to accommodate the increasing variability induced by these variable generation technology, additional storage facilities holding about two GW were likely to be built. As the capacity factor of the French nuclear power plant fleet remained unchanged, slightly increasing French exports were driven by higher wind output. The same held true for Polish lignite and hard coal power plants, which, at almost $30 \mathrm{GW}$ capacity, represented around half of the coal capacity in Eastern Europe. Due to their economic advantage over other technologies, like gas and imported electricity from Germany, they ran at full capacity in any considered scenario. In contrast, in the short-run, idle gas power plants switched online, which is in line with previous research [13]. Ten years after, additional investments in 1-3 GW of gas capacity were incentivized by a German coal-exit, presumably slightly increasing Polish net exports. Intriguingly, a more ambitious German coal-exit rather incentivized gas capacity additions, not wind. This effect is plausible for two reasons: First, coal combustion provides more than $70 \%$ of today's electricity in Poland. The majority of Polish coal power plants are older than 30 years, i.e., by 2030 older than 40 years [23], calling for replacement with a dispatchable technology. Second, decommissioned dispatchable coal capacity in Germany is partially replaced with low-carbon dispatchable gas power plants outside of Germany. Further additional gas capacity additions are likely to occur in the Netherlands and Belgium at the order of 2-3 GW between 2020 and 2030, which dispatch at times with low renewable energy sources availability. On a European level, our model results show that a German coal-exit would advance renewable energy sources. In 2030, additions across Europe total 15-20 GW of Solar PV, 8-10 GW wind and, concomitant, 5-6 GW of storage.

Germany, the largest European economy, is the main polluter within Europe. In 2017, Germany emitted $936 \mathrm{Mt} \mathrm{CO}_{2}$ equivalents, over $20 \%$ of European's overall emissions [30]. Our model results show that, without any additional policy measures, emissions from Germany's electricity sector will be higher than the emissions of Germany's neighboring countries electricity provision altogether in 2020 and 2030. This stresses the relevance of decarbonizing the German electricity sector. Figure 8 shows the effect on emissions from the power sector on Europe relative to the base case scenario (REF), differentiated by fuel type (due to our slight overestimation of available coal capacities in AT, DK and the UK emissions from coal-based generation in these countries might marginally decrease, compensated partially by higher emissions from gas generation. Yet, these changes do not change the overall dynamics illustrated here). Across all coal-exit scenarios, there is fuel switch effect from coal to gas in Germany and other European countries in both 2020 (Figure 8a) and 2030 (Figure 8b). Carbon savings associated with a German coal-exit by far outweigh additional emissions from power plants-mostly gas - that partially compensate for decommissioned coal generation. This principally occurs in Belgium, France, Italy, the Netherlands and Poland. Consequently, following dynELMOD's determination of the most cost-efficient power plant portfolio, a German coal-exit could tremendously benefit Europe's decarbonization, potentially contributing to achieving Europe's climate targets. 


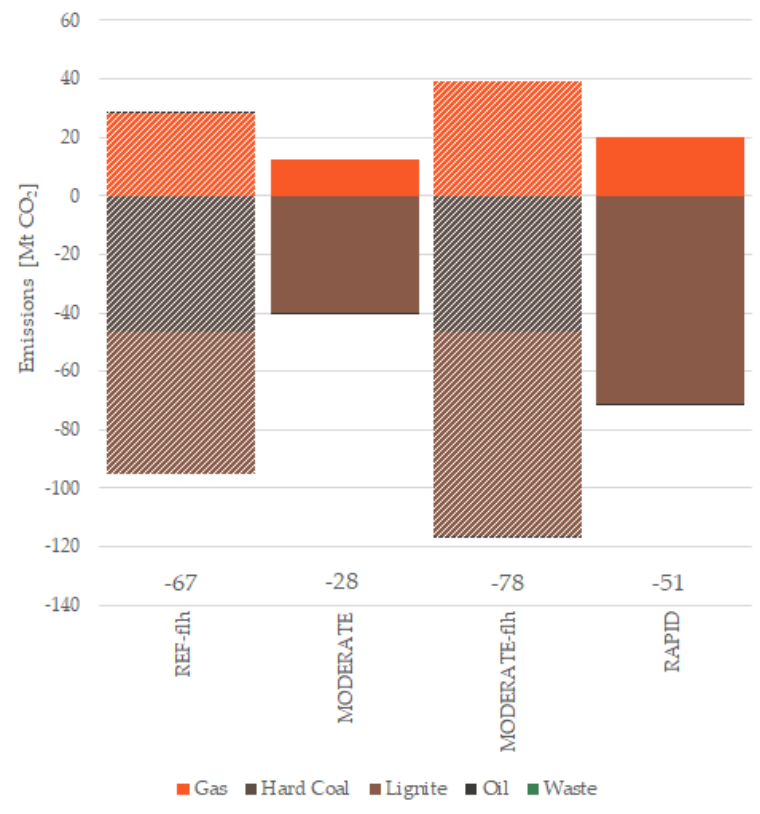

(a)

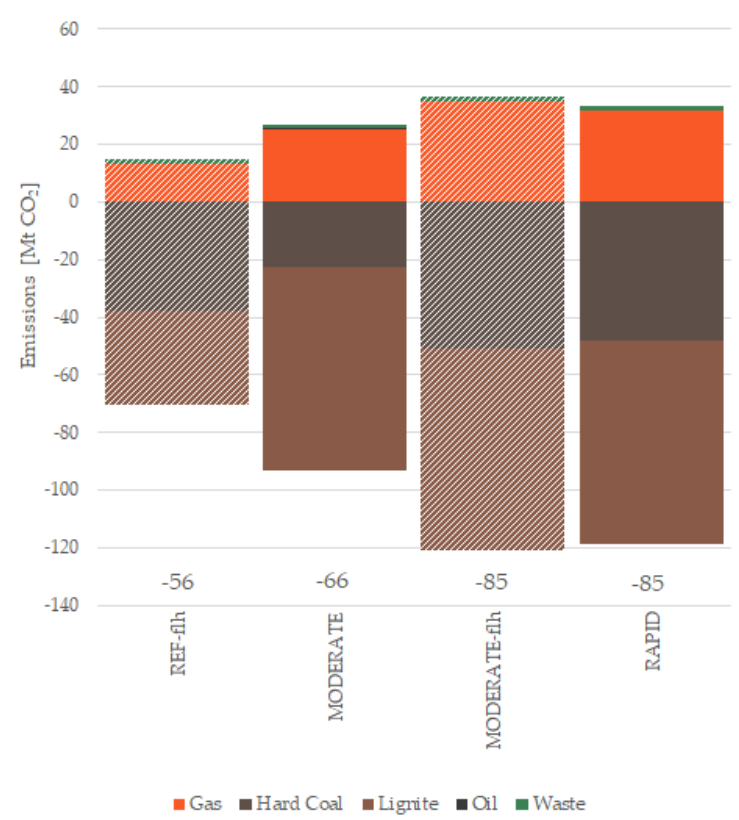

(b)

Figure 8. Shift in European emissions relative to the base case differentiated by fuel type in 2020 (a) and 2030 (b). The figures below the bars indicate net change in emissions (own calculations).

In the short-term, the strongest net reduction of almost $80 \mathrm{Mt} \mathrm{CO}_{2}$ equivalents could be realized by both imposing a limit on the full load hours of aged power plants and retiring lignite power plants. More precisely, due to the fuel switch, emissions from the power sector outside Germany rose by $29 \mathrm{Mt} \mathrm{CO}$ equivalents, yet were overcompensated by the $107 \mathrm{Mt} \mathrm{CO}_{2}$ equivalents of carbon savings within Germany. Considering the instruments separately, the limitation of the annual operating time appeared to incentivize a stronger fuel switch, going from coal to gas, with a stronger net effect on European emissions than the command and control approach: the carbon savings totaled $7 \%$ and $8 \%$ in the REF-flh and MODERATE-flh scenarios, respectively. In the MODERATE and RAPID exit scenarios, savings of $3 \%$ and $6 \%$ could be achieved.

In 2030, a German coal-exit could even yield stronger reductions, with the following simple relation: The more ambitious the coal-exit, the greater the achieved carbon savings. Both the moderate exit under full load hour restriction (MODERATE-flh) and the RAPID exit pathway could yield emission reductions on the order of $85 \mathrm{MtCO}_{2}$ equivalents, which equaled a total reduction of European emissions in the power sector of $17.5 \%$. To provide further perspective, $85 \mathrm{Mt} \mathrm{CO}_{2}$ equivalents equaled Austria's entire emissions in 2017 [30]. In both scenarios, additional emissions due to displaced generation outside Germany amounted to approximately $30 \mathrm{Mt} \mathrm{CO}_{2}$ equivalents. However, as these displaced additional emissions were more than recovered by about $115 \mathrm{MtCO}_{2}$ equivalents savings within Germany there was a positive net effect for all of Europe. In general, emission transfers did not exceed $7 \%$ of the total emissions coming from power provision in Europe; again, being tremendously overcompensated by German savings across all investigated scenarios. In Germany, the greater part of the emission reductions was due to the completed phase-out of lignite. The same holds true at the European level, as the lion's share of generation from conventional energy sources was reduced in Germany.

For the entire optimization period (2020-2050), the overall net climate impact was immense in all coal-exit scenarios. Compared to total emissions in the baseline (REF), it ranged from $193 \mathrm{Mt} \mathrm{CO}_{2}$ equivalents in the MODERATE scenario to more than $267 \mathrm{Mt} \mathrm{CO}_{2}$ equivalents in the most ambitious scenarios MODERATE-flh and RAPID. The latter was equivalent to an overall European decrease of roughly $9 \%$ compared to the baseline during the period 2020-2050. 


\subsection{Parity Burden Sharing of the Coal-Exit within Germany}

While both hard coal and lignite power plants are situated in Western Germany, only lignite is used in Eastern Germany [31]. Given the low level of industrialization in Eastern Germany, compared to Western Germany, the initial phase-out of lignite might involve social considerations $[4,32]$. Thus, we also modeled parity burden sharing between the hard coal and lignite industries for the moderate pathway, with and without the full load hour restrictions (MODERATE and MODERATE-flh). The reduction of five GW by 2020 and 14 GW in 2030 compared to the base line was equally distributed between hard coal and lignite capacities. Likewise, any negative social impact was skewed away from the Eastern-German coal regions Lusatia and the coal district in central Germany (Saxony and Saxony-Anhalt) toward North Rhine-Westphalia, which is said to be socially more resilient to industry closures [33].

Results show that, in both 2020 and 2030, carbon savings within Germany were two $\mathrm{Mt} \mathrm{CO}_{2}$ equivalents lower than in the unmodified moderate pathway, with or without limits placed on the operational time of aged power plants. This is because lignite power plants have a higher carbon-intensity than hard coal power plants. Similarly, total generation from coal remained nearly unchanged, although the ratio of lignite to hard coal increased. In terms of trade displacement, there were no significant differences to the original moderate pathway. On the European level, total emissions slightly increased in response to German decisions.

\section{Conclusions and Policy Implications}

Without phasing out coal in Germany, the country will neither meet its climate targets nor be successful at making its envisioned conversion to an electricity and energy system based on renewable energy. Therefore, this paper investigated two different tools to drive down German emissions from the electricity sector within the context of current German and European climate policy: Either by the mere retirement of coal power plants or the limitation of the operational time of older power plants that, due to their technology vintage and lower efficiency, tend to be more carbon-intensive. Different reduction pathways were modeled, visualizing the impact of a German coal-exit on carbon emissions, power plant capacities and trade flows across the European electricity market.

The calculations show that an adequate contribution to Germany's 2020 climate targets could only be achieved by imposing limits on the annual operating of coal plants. Furthermore, coal phase-out pathways in line with the coal commission's recommendation enable achieving the current 2030 climate targets in the energy sector in Germany. The German climate targets, however, will have to be adjusted due to the planned increase of the European climate target of $-40 \%$ to $-50-55 \%$ by 2030 (compared to 1990). Additionally, additional $\mathrm{CO}_{2}$ reduction is needed to compensate missed targets of the past (and most likely also 2020) as limiting global warming is dependent on the overall emitted $\mathrm{CO}_{2}$. Therefore, exceeding the existing 2030 emission target should be targeted. Furthermore, this can compensate for missed targets in other sectors.

Replacing overall capacities of $45 \mathrm{GW}$ of (formerly baseload) coal capacity with mostly fluctuating renewable energy sources over a twenty-year span imposes a major change on the existing German electricity system. Enhancing further flexibility options, e.g., storage and demand-side-management, is essential for enabling this decarbonization. Limiting annual operating time of old coal plants can help to bridge this transformation period reaching, bringing about substantial emission reductions while preserving flexible capacity. Running coal plants with lower capacity factors or as reserve units creates additional employment needs, softening the effects of regional coal phase-outs. Additionally, shifting coal closures within Germany between hard coal and lignite units or within lignite basins affected regional employment figures but only minimally influenced overall European $\mathrm{CO}_{2}$ mitigation effects.

In contrast to frequently expressed concerns, the German $\mathrm{CO}_{2}$ mitigation effect will not be offset by additional emissions in other European countries. On the contrary, our model results indicate that phasing out coal before coal power plants reach the end of their technical lifetime would incentivize overall European energy system decarbonization. In total, a German coal phase-out would reduce 
carbon emissions in Europe by up to $85 \mathrm{Mt}$ in 2030. Following the recommendations of the German coal commission, these additionally saved and not needed $\mathrm{CO}_{2}$ certificates would not be released into the ETS market, therefore guaranteeing an overall emission reduction. While the electricity trade balance of Germany might shift to becoming a net importer in some scenarios within the decade, it is likely to consolidate in the medium-run.

In order to achieve German climate targets, policy makers should seek a mandated coal phase-out in line with international climate targets. It would be economically beneficial to phase out coal-based electricity provision due to the high negative externalities associated with coal mining and electricity. Reducing full load hours, as shown within this paper, is an appropriate approach to achieve climate targets with relatively few negative effects on employment and system stability. The recommendations of the coal commission provide some valuable inputs that need implementation. The government should mandate a coal-exit accompanied by a more stringent conversion of the electricity system to accommodate renewable energy sources beyond the current expansion pathways of the Renewable Energy Sources Act [34]. It also will be necessary to include storage, potential demand-side management and intensified European integration in the considerations. It is only if Germany manages to phase out coal that it can recover its lost position as a climate and energy policy leader within the European Union.

We limit our analysis to the decarbonization of the European electricity sector, assuming additional electricity demand from the heat and transport sector. More differentiated sensitivity analysis of different speed of such sector coupling effects should be conducted in future studies. Finally, the applied time series reduction approach risks underrepresenting the extremes and the security of supply considerations; as such, it should be a matter of future research.

Author Contributions: Conceptualization, M.K., L.G. and P.-Y.O.; Data curation, M.K.; Investigation, M.K.; Methodology, M.K., L.G. and P.-Y.O.; Project administration, M.K.; Software, M.K.; Supervision, C.K., P.-Y.O. and C.v.H.; Validation, M.K. and P.-Y.O.; Visualization, M.K.; Writing-original draft, M.K., L.G. and P.-Y.O.; Writing-review and editing, M.K., L.G., P.-Y.O. and C.v.H. All authors have read and agreed to the published version of the manuscript.

Funding: This research was supported by the German Ministry for Education and Research (BMBF) under grant number 01LN1704A for the research group CoalExit and under grant number 01LA1810A/ 01LA1810B for the research project "Future of Fossil Fuels in the wake of greenhouse gas neutrality".

Conflicts of Interest: The authors declare no conflict of interest.

\section{Appendix A -The German Coal Commission and Implemented Phase-Out Pathways}

The commission consisted of four chairs and 24 representatives of industry, labor unions, environmental NGOs, climate scientists and the regions. Around one-third of the commission's members can be grouped into a "pro coal" alliance, consisting of the trade union, industry and local representatives of the lignite regions; their priority is to secure sufficient funds for the ongoing structural change. Another third forms a "pro climate" alliance of NGOs, climate scientists and local representatives pushing for a rapid coal phase-out. During the first meetings, external experts were invited to provide inputs on various topics to allow for a sufficiently fact-based decision-making process. Thereby, critics note that the choice of experts not only lacked any representatives of other countries affected by climate change and younger generations, but also comprised less than $10 \%$ women. Additionally, the government refrained from setting clear guidelines for the commission's work, which might have eased consensus talks, e.g., through setting an indisputable $\mathrm{CO}_{2}$ budget for the coal sector. The recommendations from the commission were handed to the German government at the end of January 2019. Following this, the government started discussions internally and with affected stakeholders, exploring various options to implement the recommendations. However, as of August 2019, no legal agreement has yet been reached regarding the concrete phase-out instrument or the resulting pathways for hard coal and lignite power plants.

Our modeled scenarios assume the lignite phase-out occurring before the hard coal phase-out for a number of reasons: First, lignite is the most carbon-intensive primary energy carrier; thus, it releases more greenhouse gases than hard coal when combusted. Second, while many firms operate hard coal 
power plants in Germany, there are only two major players in the lignite industry (RWE AG and EPH Holding), rendering the implementation of a phase-out agreement possible at an earlier stage than one for hard coal. Finally, hard coal power plants are rather integrated, not only into power, but also heat and industrial, provision. Decarbonizing the heat and industry sector might require hard coal power plants to remain online for more years compared to lignite units.

\section{Appendix B -Additional Scenario Assumptions}

The scenarios are benchmarked against Germany's climate targets for 2020, 2030 and 2050. As we seek to investigate ways that Germany can achieve its emission reduction targets in the near future and since the decarbonization of the heating sector is expected to be more difficult than the electricity sector [35], we assume that the energy sector's emission reductions must be fully realized within the electricity sector. Since there are no sector targets for 2020 in Germany, we impose a 40 percent emission reduction target for the electricity sector, which equals Germany's overall greenhouse gas emission target [36]. The energy sector's emissions in 1990 totaled $466 \mathrm{Mt} \mathrm{CO}_{2}$ equivalents, with $382 \mathrm{Mt} \mathrm{CO}_{2}$ equivalents from power provision (own calculations based on $[37,38]$ ). A small proportion of the greenhouse gases emitted by small distributed resources that cannot be attributed to a specific source, thus being assigned to "others" are estimated to be on the order of $20 \mathrm{Mt} \mathrm{CO} 2$ equivalents in 2016 [37]. This proportion cannot be represented in the model, hence entering it exogenously, extrapolated to 2020 (12 Mt CO2) and 2030 (8 Mt CO2) according to the German government's reduction targets. The maximum emissions, in line with the 2020 target, were bounded by $217 \mathrm{Mt} \mathrm{CO}_{2}$ equivalents. The 2030 targets are specified in the climate protection plan for 2050 [39]. While the plan stipulates minimum greenhouse gas emission reduction targets for each energy-intensive sector-that is, energy, buildings, industry, transport and agriculture-it does not explicitly differentiate between emissions from the provision of electricity and heat by the energy sector. On the contrary, both electricity and heat supply are treated as a whole and subsumed under one energy sector. The energy sector's minimum target is a 61 percent emission reduction compared to its emission level in the base year 1990, yielding a limit of greenhouse gases emitted by power sector of $141 \mathrm{Mt} \mathrm{CO}_{2}$ equivalents in 2030 . The 2050 targets are aligned with the decarbonization pathway envisaged by the European Union that mandates an overall reduction of $98 \%$ by 2050 (see Scenario: "Diversified supply scenario" in Annex 1 Scenarios-assumptions and results page 70; row Power generation/District heating in [16]). For each modeled year, an exogenous emission budget in line with the $98 \%$ emission reduction target laid out by the European Commission [16] is implemented. Noteworthy, biomass is regarded as carbon-neutral. Renewable expansion is aligned with the Renewable Energy Sources Act and the current coalition contract of the federal government, which stipulate a share of the German electricity consumption generated by renewable energy sources of $45 \%$ by 2025 and $65 \%$ by 2030 [34,39]. Finally, the Belgian nuclear power plant fleet is prone to malfunctions and is frequently unavailable; thus, we assume the remaining plants Doel and Tihange will be decommissioned by 2020.

\section{References}

1. BMU. Projektionsbericht 2019 für Deutschland Gemäß Verordnung (EU) Nr. 525/2013; Bundesumweltministerium: Berlin, Germany, 2019.

2. Oei, P.-Y.; Brauers, H.; Herpich, P. Lessons from Germany's Hard Coal Mining Phase-out: Policies and Transition from 1950 to 2018. Clim. Policy 2019. [CrossRef]

3. Stognief, N.; Walk, P.; Schöttker, O.; Oei, P.-Y. Economic Resilience of German Lignite Regions in Transition. Sustainability 2019, 11, 5991. [CrossRef]

4. Oei, P.-Y. Greenhouse Gas Emission Reductions and the Phasing-out of Coal in Germany. In Energiewende "Made in Germany"-Low Carbon Electricity Sector Reform in the European Context; von Hirschhausen, C., Gerbaulet, C., Kemfert, C., Lorenz, C., Oei, P.-Y., Eds.; Springer International Publishing: Berlin, Germany, 2018; ISBN 978-3-319-95125-6. 
5. Rinscheid, A.; Wüstenhagen, R. Germany's decision to phase out coal by 2038 lags behind citizens' timing preferences. Nat. Energy 2019, 4, 856-863. [CrossRef] [PubMed]

6. Oei, P.-Y.; Hermann, H.; Herpich, P.; Holtemöller, O.; Lünenbürger, B.; Schult, C. Coal phase-out in Germany-Implications and policies for affected regions. Energy 2020, 196, 117004. [CrossRef]

7. BMWi. Commission on Growth, Structural Change and Employment_Final Report; Federal Ministry for Economic Affairs and Energy (BMWi): Berlin, Germany, 2019.

8. Parra, P.Y.; Roming, N.; Sferra, F.; Schaeffer, M.; Fuentes Hutfilter, U.; Zimmer, A.; Aboumahboub, T.; Hare, B. Science Based Coal Phase-out Pathway for Germany in Line with the Paris Agreement $1.5{ }^{\circ} \mathrm{C}$ Warming Limit: Opportunities and Benefits of an Accelerated Energy Transition; Climate Analytics: Berlin, Germany, 2018.

9. Göke, L.; Kittel, M.; Kemfert, C.; Oei, P.-Y.; von Hirschhausen, C. Scenarios for the Coal Phase-out in German-A Model-Based Analysis and Implications for Supply Security; DIW Weekly Report 28/2018; DIW Berlin, German Institute for Economic Research: Berlin, Germany, 2018.

10. Gierkink, M.; Lencz, D.; Arnold, F. Auswirkungen einer Beendigung der Kohleverstromung bis 2038 auf den Strommarkt, CO2-Emissionen und ausgewählte Industrien. Eine Analyse des Abschlussberichts der WSB-Kommission. Im Auftrag des Ministeriums für Wirtschaft, Innovation, Digitalisierung und Energie des Landes Nordrhein-Westfalen Endbericht, August 2019; Energiewirtschaftliches Institut an der Universität zu Köln gGmbH (EWI): Köln, Germany, 2019.

11. Gerbaulet, C.; Lorenz, C. dynELMOD: A Dynamic Investment and Dispatch Model for the Future European Electricity Market; DIW Berlin: Berlin, Germany, 2017.

12. Heinrichs, H.U.; Markewitz, P. Long-term impacts of a coal phase-out in Germany as part of a greenhouse gas mitigation strategy. Appl. Energy 2017, 192, 234-246. [CrossRef]

13. Wilson, I.A.G.; Staffell, I. Rapid fuel switching from coal to natural gas through effective carbon pricing. Nat. Energy 2018, 3, 365-372. [CrossRef]

14. Osorio, S.; Pietzcker, R.C.; Pahle, M.; Edenhofer, O. How to Deal with the Risks of Phasing out Coal in Germany through National Carbon Pricing; CESifo: Munich, Germany, 2018.

15. Oei, P.-Y.; Brauers, H.; Kemfert, C.; Kittel, M.; Göke, L.; von Hirschhausen, C.; Walk, P. Kohleausstieg in NRW im deutschen und europäischen Kontext_Energiewirtschaft, Klimaziele und wirtschaftliche Entwicklung; Politikberatung Kompakt; DIW Berlin: Berlin, Germany, 2018.

16. EC. Energy Roadmap 2050: Impact Assessment, Part 1/2; Commission Staff Working Paper; European Commission: Brussels, Belgium, 2011.

17. Requate, T. Dynamic incentives by environmental policy instruments-A survey. Ecol. Econ. 2005, 54, 175-195. [CrossRef]

18. Oei, P.-Y.; Gerbaulet, C.; Kemfert, C.; Kunz, F.; von Hirschhausen, C. Auswirkungen von $\mathrm{CO}_{2}$-Grenzwerten für Fossile Kraftwerke auf den Strommarkt und Klimaschutz; Politikberatung Kompakt; DIW: Berlin, Germany, 2015.

19. SRU. Start Coal Phaseout Now; Secretariat, German Advisory Council on the Environment (SRU): Berlin, Germany, 2017.

20. Ziehm, C.; Kemfert, C.; Oei, P.-Y.; Reitz, F.; von Hirschhausen, C. Entwurf und Erläuterung für ein Gesetz zur Festsetzung Nationaler CO2-Emissionsstandards für Fossile Kraftwerke in Deutschland; DIW Berlin: Berlin, Germany, 2014; ISBN 978-3-938762-73-8.

21. Schäuble, D.; Volkert, D.; Jacobs, D.; Töpfer, $\mathrm{K}$. $\mathrm{CO}_{2}$-Emissionsgrenzwerte für Kraftwerke-Ausgestaltungsansätze und Bewertung Einer möglichen Einführung auf Nationaler Ebene; IASS Working Paper; Institute for Advanced Sustainability Studies: Potsdam, Germany, 2014.

22. Wynn, G.; Coghe, P. Europe's Coal-Fired Power Plants: Rough Times Ahead Analysis of the Impact of a New Round of Pollution Controls; Institute for Energy Economics and Financial Analysis: Cleveland, OH, USA, 2017.

23. Europe beyond Coal European Coal Plant Database. Available online: https://beyond-coal.eu/data/ (accessed on 9 November 2018).

24. Huneke, F.; Lenck, T. Kurzanalyse zur Stromerzeugung bei Netzbedingter Abregelung Erneuerbarer Energien; Energy Brainpool: Berlin, Germany, 2016.

25. Hein, F.; Peter, F.; Graichen, P. Auswirkungen der Corona-Krise aufdie Klimabilanz Deutschlands_Eine Abschätzung der Emissionen 2020; Agora Energiewende: Berlin, Germany, 2020.

26. IFEU. Aktualisierung, Daten- und Rechenmodell: Energieverbrauch und Schadstoffemissionen des Motorisierten Verkehrs in Deutschland 1960-2035“(TREMOD) für die Emissionsberichterstattung 2016 (Berichtsperiode 1990-2014); IFEU: Heidelberg, Germany, 2016. 
27. EC. Communication from the Commission to the European Parliament, the European Council, the Council, the European Economic and Social Committee and the Committee of the Regions-The European Green Deal; European Commission: Brussels, Belgium, 2019.

28. Oei, P.-Y.; Hainsch, K.; Löffler, K.; von Hirschhausen, C.; Holz, F.; Kemfert, C. A new climate for Europe: 2030 climate targets must be more ambitious. DIW Wkly. Rep. 2019, 9, 365-372.

29. Peter, F.; Litz, P. Kohleausstieg, Stromimporte und -Exporte Sowie Versorgungssicherheit; Kurz-Analyse; Agora Energiewende: Berlin, Germany, 2017.

30. EEA. EEA Greenhouse Gas-Data Viewer. Available online: https://www.eea.europa.eu/data-and-maps/ data/data-viewers/greenhouse-gases-viewer (accessed on 4 November 2019).

31. DIW Berlin; Wuppertal Institute; Ecologic Institute. Phasing out Coal in the German Energy Sector. Interdependencies, Challenges and Potential Solutions; German Institute for Economic Research (DIW Berlin): Berlin, Germany; Wuppertal Institute for Climate, Environment and Energy: Wuppertal, Germany; Ecologic Institute: Berlin, Germany, 2019.

32. Brauers, H.; Herpich, P.; Von Hirschhausen, C.; Jürgens, I.; Neuhoff, K.; Oei, P.-Y.; Richstein, J. Coal Transition in Germany -Learning from Past Transitions to Build Phase-out Pathways; IDDRI and Climate Strategies: Berlin, Germany, 2018.

33. Oei, P.-Y.; Lorenz, C.; Schmalz, S.; Brauers, H.; Herpich, P.; von Hirschhausen, C.; Kemfert, C.; Dröschel, B.; Hildebrand, J.; Horst, J.; et al. Klimaschutz und Kohleausstieg: Politische Strategien und Maßnahmen bis 2030 und Darüber Hinaus; Climate Change 27/19; Federal Environment Agency Germany: Dessau-Roßlau, Germany, 2019.

34. BMJV. Gesetz für den Ausbau Erneuerbarer Energien (Erneuerbare-Energien-Gesetz-EEG 2017); Bundesministerium der Justiz und für Verbraucherschutz: Berlin, Germany, 2017.

35. Stryi-Hipp, G.; Horst, J.; Lenz, V.; Thran, D.; Rockendorf, G.; Schüwer, D.; Sperber, E.; Erhorn, H. Besonderheiten des Wärmemarktes und Konsequenzen für eine erfolgreiche Wärmewende. In Proceedings of the Forschung für die Wärmewende Jahrestagung 2015 des ForschungsVerbunds Erneuerbare Energien, Berlin, Germany, 3-4 November 2015; pp. 23-26.

36. Federal Network Agency. Sechster Monitoringbericht zur Energiewende-Berichtsjahr 2016; Federal Network Agency: Bonn, Germany, 2018.

37. UBA. Entwicklung der Spezifischen Kohlendioxid- Emissionen des Deutschen Strommix in den Jahren 1990-2018; Umweltbundesamt: Dessau-Roßlau, Germany, 2019.

38. BMUB. Klimaschutzplan 2050—Klimaschutzpolitische Grundsätze und Ziele der Bundesregierung; Bundesministerium für Umwelt, Naturschutz und Reaktorsicherheit: Berlin, Germany, 2016.

39. CDU, CSU, SPD. Ein neuer Aufbruch für Europa. Eine neue Dynamik für Deutschland. Ein neuer Zusammenhalt für unser Land. Koalitionsvertrag zwischen CDU, CSU und SPD. Koalitionsvertrag der 19. Legislaturperiode.; Bundesregierung: Berlin, Germany, 2018. 